\title{
Betydelsen av historisk rättvisa efter kolonialismen
}

\author{
Göran Collste \\ Centrum för tillämpad etik, Linköpings universitet, goran.collste@liu.se
}

Artikeln tar sin utgångspunkt i två aktuella exempel på krav på historisk rättvisa efter kolonialismen: forna Mau-Mau-kämpars krav på gottgörelse för britternas övergrepp på 1950talet och hererofolkets krav till Tyskland på gottgörelse för det folkmord som ägde rum 19041907. Dessa exempel aktualiserar frågan om historisk rättvisa. Vad innebär historisk rättvisa? Vilka krav på historisk rättvisa är berättigade att ställa? Hur lång tid efter övergrepp och våld finns det skäl att kräva gottgörelse? Kan kraven ärvas till efterkommande generationer? Vem bör gottgöra dem som drabbats? Dessa frågor måste besvaras för att man skall kunna ta ställning till krav på gottgörelse och rättvisa. Syftet med denna artikel är att identifiera och söka besvara en rad frågor som krav på gottgörande rättvisa efter kolonialismen ställer. Avslutningsvis diskuteras kraven från Mau-Mau-kämparna som var internerade $i$ brittiska läger och hererofolkets krav på kompensation från Tyskland.

Nyckelord: Gottgörande rättvisa, kompensation, kolonialism, herero, Mau-Mau, global rättvisa, historisk rättvisa

\section{English summary: The Meaning of Historical Justice after Colonialism}

Recently, four Kikuyus and former Kenyan Mau-Mau fighters claimed compensation for castration, torture and rape committed in the British detention camps in the 1950s. Also recently, representatives of the Herero people went to Berlin to bring home skulls that Germans brought to Berlin after the genocide at the beginning of the Twentieth Century. The detentions and abuses of Kikuyu and the genocide of the Herero people are just two examples of offenses carried out by European nations during colonialism. Do these offenses have any reverberations today? Should we simply forget about the deeds that happened such a long time ago or do they raise any legal or moral questions?

The concept of justice has two dimensions, distributional and rectificatory. This article focuses on the meaning and implication of rectificatory justice for historical wrongs. The simple idea that if $A$ is harming $B, A$ has to correct her act, i.e. the basic idea of rectificatory justice, presupposes a line of complicated assumptions when it is applied to specific historical incidences, for example colonialism.

A model provides a basis for an explication of rectificatory justice. It is then applied to a discussion of rectification after colonialism. The questions of who can rightly claim rectification and who owes rectification, if there are temporal limitations to rectification and what rectification after colonialism would imply are discussed. The article ends with an explica- 
tion of the meaning of rectificatory justice, an argumentation for why rectificatory justice is commendable and an assessment of the demands of the Mau-Mau-fighters and the Herero.

Keywords: Rectificatory justice, compensation, colonialism, Herero, Mau-Mau, global justice, historical justice.

\section{Inledning}

Den 21 juli 2011 beslöt en engelsk domstol att låta pröva brott som begåtts mot kenyaner under upproret mot det brittiska kolonialväldet. Det är ett beslut som kan komma att få stora följder för frågan om historisk rättvisa efter kolonialismen.

I april kom fyra äldre kenyaner till London. De var några av tusentals offer för engelsmännens krig mot Mau-Mau-rörelsen i Kenya för över 50 år sedan. De fyra, tre män och en kvinna, hade utsatts för olika övergrepp såsom kastrering, tortyr och våldtäkt i brittiska interneringsläger. De representerar omkring ett tusen kenyaner som fortfarande lever och som utsattes för liknande behandling.

Under befrielsekriget mot den engelska kolonialmakten, som så småningom ledde till Kenyas självständighet 1963 och där f.ö. president Obamas farfar deltog, sattes tiotusentals misstänkta oppositionella i läger. Kenyas kommission för mänskliga rättigheter beräknar att ungefär 600000 människor internerades och att 90000 av dem torterades eller misshandlades i lägren. Under kriget beräknas $20000 \mathrm{Mau}-\mathrm{Mau}$-soldater ha dödats (Anderson 2005).

Strax innan engelsmännen var tvungna att lämna Kenya skeppades många lådor med dokumentation om vad som hänt under kolonialkriget och i interneringslägren till England. Samma sak skedde när man lämnade sina andra kolonier. Dokumenten har sedan förvarats i utrikesdepartementets lokaler utan att någon haft tillgång till dem. De har nu äntligen blivit offentliga och de visar att den engelska regeringen var väl medveten om vilka metoder som användes mot de oppositionella i lägren.

$\mathrm{Nu}$ går ärendet vidare i brittisk domstol. Den brittiska regeringen slår ifrån sig och hävdar att ansvaret för lägren låg hos den koloniala myndigheten, att ansvaret övergick till Kenyas regering vid självständigheten (!), att brotten mot mänskliga rättigheter hände för så lång tid sedan och att de därför är preskriberade. Vilken dom som kommer att avkunnas vet vi inte idag. Det kan visa sig vara omöjligt att uppfylla juridiska krav på bevisning och exakt fastslå vilka brott som begicks för över femtio år sedan (Casciani 2011, för en redogörelse för britternas krig mot Mau-Mau-rörelsen, se Anderson 2005).

I september 2011 kom en delegation från hererofolket i Namibia ledd av hövdingen Kuiama Riruako till Berlin. Syftet med besöket var att hämta hem tjugo människoskallar som hade förts till Tyskland efter folkmordet på herero mellan åren 1904-1907. «För oss betyder det att våra släktingar, far- och morföräldrar kommer hem», sa Ida Hoffman som ingick i delegationen (The Telegraph 2011).

Besöket kastade ljus över de massakrer som utfördes av tyska soldater under ledning av general Lothar van Trotta. Van Trotta stod under kejsar Wilhelm II:s befäl när han 
beordrade utrotning av hererofolket som en hämnd för att de hotat de tyska invandrarna i den tyska kolonin Sydvästafrika. Van Trotta skriver själv: «Min politik är att utöva våld, terrorisera med hårda medel. Jag utplånar de afrikanska stammarna med strömmar av blod och pengar. Endast genom en sådan utrensning kan något nytt och bestående komma» (cit. i Gewald 1990: 190).

De tyska soldaterna var militärt överlägsna och dödade mängder av herero, medan andra herero drevs ut i öknen där de törstade ihjäl. Före massakrerna uppgick antalet herero till cirka 80 000, efter folkmordet fanns det 15000 överlevande kvar (Sarkin-Hughes 2011).

Besöket i Berlin hade föregåtts av krav på kompensation och krigsskadestånd från representanter för hererofolket, framförda bland annat när den tyske förbundskanslern Helmut Kohl besökte Windhoek i Namibia 1995 (Gewald 1990).

Forna Mau-Mau-kämpar som internerades i brittiska fångläger har nu gått till brittisk domstol. Men den fråga som kommer upp i de brittiska domstolarna har inte bara en juridisk sida. Det handlar om historisk rättvisa, om upprättelse av dem som blivit kränkta. Det är en etisk fråga lika mycket som en juridisk. Detsamma gäller hererofolkets krav. Här liknar fallen med kenyanerna och herero de krav på upprättelse och belysning av historiska orättvisor som nyligen tagits upp i Sverige av kommissioner som undersökt myndigheters behandling av romer och tvångsomhändertaganden av barn som placerats i fosterhem. Även om man idag inte kan ställa de ansvariga ämbetsmännen inför rätta för övergrepp mot romer respektive fosterbarn har kommissionerna rekommenderat en rad åtgärder som syftar till att uppmärksamma de historiska övergreppen och upprätta och kompensera offren.

Vad innebär historisk rättvisa? Vilka krav på historisk rättvisa är berättigade att ställa? Hur lång tid efter övergreppen finns det skäl att kräva gottgörelse? Kan kraven - och ansvaret - ärvas av efterkommande generationer? Vem bör gottgöra dem som drabbats? Dessa frågor måste besvaras för att man skall kunna ta ställning till krav på gottgörelse och rättvisa. Syftet med denna artikel är att identifiera och söka besvara en rad frågor som krav på gottgörande rättvisa ställer. Avslutningsvis bedöms kraven från dem som var internerade i brittiska läger samt hererofolkets krav på kompensation.

De frågor som tas upp i denna artikel har aktualiserats av en lång rad krav på historisk rättvisa. Det gäller exempelvis kompensation till judarna efter Förintelsen (Barkan 2000), de svarta i USA som krävt kompensation för slaveriet (Brophy 2006), krav från ursprungsbefolkningar såsom aboriginerna i Australien (Thompson 2000), sanningsoch försoningsprocessen efter apartheid i Sydafrika (Villa-Vicencio 2009) och processerna efter militärdiktaturerna i Latinamerika (Lean 2003). Artikelns utgångspunkt är två aktuella exempel på krav på gottgörelse efter kolonialismen. Varje historisk situation är unik och frågan om huruvida krav på gottgörelse för historiska oförrätter är berättigade eller ej måste avgöras utifrån de specifika omständigheter som föreligger. Det finns dock också en rad principiella frågor rörande gottgörande rättvisa som är gemensamma för olika fall. Det är dessa principiella frågor som behandlas i artikeln. Den vidare kontexten utgörs av frågan om vilka krav på gottgörelse efter kolonialismen som kan vara berättigade. 
Krav på historisk rättvisa kan gälla enskilda händelser såsom en massaker på civila och tortyr av fångar eller mer generella politiska handlingar som krigföring eller kolonisering av ett annat land. I denna artikel diskuteras historisk rättvisa efter kolonialismen både utifrån konkreta händelser och mer övergripande skeenden. «Colonialism is a practice of domination, which involves the subjugation of one people to another», enligt Stanford Encyclopedia of Philosophy. Kolonialismen uppfattas av afrikaner som Förintelsen uppfattas av judar, menar Villa-Vicencio (2009). För kolonialmakterna var det viktigt att dra ett streck över historien när kolonierna blev självständiga och kolonierna som nu blivit självständiga men fortfarande var beroende av sina forna herrar fogade sig. Det kan förklara varför krav på gottgörelse efter kolonialismen inte varit särskilt vanliga. Ett undantag utgör dock FN-konferensen om rasism i Durban 2001. I konferensens slutdeklaration formulerades krav på gottgörelse efter kolonialismen och i synnerhet för slavhandeln. Även representanter för ursprungsbefolkningar som undanträngdes av kolonisatörer, såsom exempelvis aboriginerna i Australien och indianstammar i Nordamerika, har krävt gottgörelse.

\section{Historisk rättvisa}

Rättvisa är ett mångfacetterat begrepp. Aristoteles skiljer mellan distributiv rättvisa och återställande rättvisa. Den distributiva rättvisan handlar om fördelning av begränsade resurser, medan den återställande rättvisan är bakåtblickande och fokuserar på gottgörelse för tidigare handlingar. Aristoteles förklarar innebörden av återställande rättvisa på följande vis:

... ifall den ena har gjort orätt och den andre varit utsatt för det eller om den ena har åstadkommit någon skada och den andra lidit någon förlust. Följaktligen försöker domaren, då denna orättvisa innebär en ojämnhet, återställa balansen. (Aristoteles 1988: V: 4)

Om kolonialismen innebar att - med Aristoteles ord - «...den ena har åstadkommit någon skada och den andra lidit någon förlust...» har vi i enlighet med Aristoteles syn ett prima facie-argument för återställande rättvisa. Men vad innebär återställande rättvisa om det har gått lång tid sedan övergreppen utfördes?

En teori om historisk rättvisa kan också hämta stöd från senare arbeten inom filosofin. Enligt John Locke innebär rättvisa bland annat en rätt till gottgörelse. Om någon utsätts för skada har hon en rättighet att kräva gottgörelse av den som utsatt henne för skadan (Locke 1977). Robert Nozick bygger sin teori om rättvisa på Locke. Enligt Nozick är en person berättigad till sin egendom under förutsättning att den har förvärvats på ett rätt sätt. Äganderätt bygger på rätt tillägnande och rätt överföring (Nozick 1974). Nozicks teori innebär ett filosofiskt rättfärdigande av libertarianismen. Den kan dock utifrån vissa andra faktaantaganden än de Nozick utgår från rättfärdiga krav på återställande rättvisa efter kolonialismen. Om vi antar att den nutida koncentrationen av ägande och välstånd i den rika delen av världen åtminstone till en del är resultatet av erövringar, plundringar och krig under kolonialtiden kan man utifrån Nozicks teori argumentera för ett «... åter- 
ställande av orättvist ägande» (Nozick 1974: 152). Historiska orättvisor ger upphov till krav på återställande handlingar. David Lyons diskussion om det finns skäl för att amerikanska delstater bör lämna tillbaka land till indianstammar som beslagstogs under koloniseringen av Amerika är exempel på detta (Lyons 1982).

Nozick utvecklar en princip för återställande rättvisa. Ett krav på återställande rättvisa bygger enligt Nozick på historisk information om den orätta handlingen, vad som hänt därefter och en bedömning av vad som skulle ha hänt om den orätta handlingen inte utförts (Nozick 1974). En bedömning av vad som hade hänt utan den orätta handlingen är hypotetisk och vilar på osäkra kontrafaktiska antaganden invänder Jeremy Waldron (Waldron 1992). En sådan hypotetisk bedömning kan dock enligt Nozick ge oss en uppskattning av vad gottgörelse skulle kunna innebära. I en sällan uppmärksammad kommentar hävdar Nozick att $i$ avsaknad av någon tillförlitlig metod för att göra en sådan bedömning skulle man kunna använda Rawls differensprincip som tumregel. Man kan anta, menar Nozick, att det är den sämst ställda gruppen i samhället som har drabbats hårdast av tidigare orättvisor (Nozick 1974).

Vi har så här långt mött tre typer av återställande rättvisa. Aristoteles argumenterar främst för att kompensera en orätt «lika för lika» för att uppnå en status quo ante, d.v.s. ett tillstånd som rådde före orättvisan. Locke argumenterar för en rätt till gottgörelse medan Nozick argumenterar för en gottgörelse av tidigare orätt tillägnande och överföring av egendom. Det de har gemensamt är uppfattningen att tidigare händelser har betydelse för den nutida diskussionen om rättvisa.

Den enkla principen att om A tillfogar B skada har A en skyldighet att gottgöra B, d.v.s. den grundläggande tanken om återställande rättvisa, rymmer en rad komplicerade antaganden när den tillämpas på konkreta historiska händelser och skeenden och jag skall i det följande diskutera vissa frågor som principen reser.

\section{Den tillbakablickande rättvisans terminologi}

Detta avsnitt fokuserar på den tillbakablickande rättvisans terminologi och begrepp. I diskussionen används flera termer: återställande rättvisa, gottgörande rättvisa, kompensatorisk rättvisa, korrigerande rättvisa etc. Det finns därför ett behov av begreppsliga distinktioner och av att tydligare ange innebörden av vissa centrala termer.

Den grundläggande idén för tillbakablickande rättvisa är att om någon har tillfogats skada innebär rättvisa att skadan kompenseras eller gottgörs så att tillståndet utjämnas och de negativa verkningarna upphör. Man brukar säga att status quo ante (tillståndet innan) har uppnåtts. Detta är den bokstavliga meningen av återställande rättvisa.

I jämförelse med begreppet återställande rättvisa är begreppen kompensatorisk och gottgörande rättvisa mindre precisa när det gäller målet för den gottgörande handlingen. Att kompensera för en förlust eller en skada betyder inte nödvändigtvis att återställa i meningen att återupprätta status quo ante. Status quo ante är inte det enda alternativet om målet är att kompensera den som utsatts för en skada. Rättvisa kan skipas på en rad andra sätt. Vi kan ta ett dammprojekt som kräver att invånare i en by måste flytta som exempel. 
Rättvisan kräver att byborna kompenseras, men det kan ske genom en rad olika åtgärder: de kan erbjudas att bo i en identisk by som är byggd i närheten, att flytta till ett grannskap som skiljer sig från den ursprungliga byn eller att erhålla ekonomisk kompensation. Begreppet kompensatorisk rättvisa kan användas för alla alternativen, men återställande rättvisa enbart för det första alternativet.

I diskussioner om historisk rättvisa efter perioder av förtryck och övergrepp bör begreppsbildningen styras av vilken typ av övergrepp eller kränkning som avses. Handlar det till exempel om en ockupationsmakts stöld av värdefulla kulturföremål kan historisk rättvisa innebära att föremålen ges tillbaka, d.v.s. återställande rättvisa. Handlar det istället som i exemplet med herero om folkmord är gottgörande rättvisa ett lämpligare begrepp. Det är knappast rimligt att diskutera den historiska rättvisan efter denna typ av koloniala övergrepp i termer av status quo ante; vad skulle detta alls kunna betyda? Frågan gäller snarare hur övergrepp under kolonialtiden skulle kunna gottgöras idag.

Ett problem med begreppet kompensatorisk rättvisa är att det har en materiell anstrykning. Den förorättade parten skall erhålla ersättning för sin skada och kompensation ges i form av pengar (se Satz 2007; Torpey 2003). Många fall av historisk rättvisa handlar dock om annat än pengar. Den förorättade parten kan exempelvis ställa krav på förlåtelse, ett återupprättande av relationer, försoning etc. Mot denna bakgrund är gottgörande rättvisa, som är ett mer inkluderande begrepp, ofta att föredra framför kompensatorisk rättvisa.

Aristoteles närmast aritmetiska rättviseuppfattning är problematisk. Även om han har rätt i att rättvisan kräver kompensation eller gottgörelse för oförrätter är det ofta orimligt att gottgörelsen skall leda till en utjämning. Diskussionen om gottgörelse för övergrepp utförda av en kolonialmakt kan exempelvis handla om exploatering av människor och naturtillgångar, slaveri samt folkmord. Det övergår den skyldige partens, d.v.s. den forna kolonialmaktens, förmåga att kunna gottgöra för sådana illdåd.

Idén om jämlikhet kan dock vara relevant för diskussionen om gottgörande rättvisa $\mathrm{i}$ en annan mening än den som Aristoteles tänkte sig. Jämlikhet kan ha flera betydelser. Det kan t.ex. innebära «treating people as equals», som filosofen Will Kymlicka skriver (Kymlicka 2002: 3). Utifrån en sådan betydelse av jämlikhet kan ett möjligt mål för gottgörande rättvisa vara att en tidigare relation mellan förövare och offer som kännetecknats av ojämlika herre-slavrelationer förändras till en relation som kännetecknas av jämlikhet och ömsesidig respekt.

Vad krävs då mer precist för att uppnå gottgörelse? Vi utgår från en situation där någon (individ eller grupp) har utsatts för ett övergrepp. Enligt filosofen Renée Hill betyder gottgörelse att skadan har kompenserats och att den som utsattes för övergreppet «is made whole ...», vilket innebär att hon mår lika bra som innan övergreppet inträffade (Hill 2004: 398). Däremot är inte en ursäkt ett nödvändigt villkor för gottgörande rättvisa enligt Hill. Hennes motivering är att en ursäkt förutsätter en inre motivation hos förövaren som är svår att fastställa i en rättsprocess. Hills perspektiv är således juridiskt. Däremot ur ett etiskt perspektiv är kompensation ofta inte ett tillräckligt villkor för gottgörelse. För att rättvisa skall uppnås krävs dessutom att förövaren inser och erkänner sitt övergrepp. Förövaren bör också försäkra att handlingen inte skall upprepas. Slutligen 
innebär gottgörande rättvisa att offren upprättas och en ny relation som kännetecknas av ömsesidig respekt uppstår mellan förövare och offer. Gottgörande rättvisa uppnås således först när

1 förövaren erkänner sitt övergrepp och ber om ursäkt,

2 de skador som övergreppet medförde har kompenserats,

3 förövaren lovar att övergreppet (inklusive likartade handlingar) inte skall upprepas och

4 relationen mellan förövare och offer kännetecknas av ömsesidig respekt.

Gottgörande rättvisa har därmed både en tillbakablickande och en framåtblickande sida. Hur är då gottgörande rättvisa relaterad till retributiv rättvisa? Gottgörande rättvisa definieras av de fyra villkor som angivits ovan. Retributiv rättvisa refererar till en person eller grupp (t.ex. en nation) som bör bestraffas på grund av någon orätt handling. Det finns ett samband mellan retributiv rättvisa och gottgörande rättvisa. Straffet som är en del av retributiv rättvisa kan ofta innebära krav på gottgörelse till offret. Exempelvis kan en nation som bestraffas för angreppskrig av en internationell domstol tvingas att kompensera den angripna nationen.

\section{En modell för gottgörande rättvisa}

Med hjälp av en modell skall jag nu strukturera begreppet gottgörande rättvisa:

\section{Modell GR}

$\mathrm{X}$ (agenten; person, grupp, nation etc.), gjorde A (ett övergrepp; stöld, mord, förtryck etc.), mot $Y$ (offret; en person, grupp, nation etc.), vid tidpunkten $\mathrm{t}$, innebär att

I X' är skyldig att kompensera Y' (X' och Y' står för X och Y vid ett senare tillfälle), med B (pengar, ursäkt etc.), och

II X' erkänner övergreppet,

III X' försäkrar att övergreppet inte skall upprepas, vilket leder till att

IV relationen mellan X' och Y' kan utmärkas av ömsesidig respekt.

Denna modell är en explikation av begreppet gottgörande rättvisa. Jag kommer i det följande att tillämpa den på diskussionen om historisk gottgörelse efter kolonialismen. Den första frågan är vilka som var agenter. För att fastställa vem som står i skuld och vem som kan kräva gottgörelse måste vi mer precist kunna identifiera förövare och offer. Den andra frågan är vilka orätta handlingar som utfördes mot vem. Gottgörande rättvisa är tillbakablickande och frågan är hur långt tillbaka i tiden som man kan gå. Finns det en bortre tidsgräns för skuld och gottgörelse? Skulden för illdåd som utfördes för 500 år 
sedan är rimligen för länge sedan utsuddad, medan konsekvenser av illdåd för säg fem år sedan i allmänhet fortfarande är kännbara. Efter att en viss tid har förflutit efter ett övergrepp anpassar sig offren till den nya situationen och skadorna förbleknar.

\section{Vilka var agenterna?}

Vilka var agenterna (i min modell «X»)? När det gäller exemplet med Mau-Mau-offren var det brittiska kolonialtjänstemän och soldater som tillsammans med lojala kenyaner inrättade interneringslägren. Detta gjordes med den brittiska regeringens goda minne så även Storbritannien som nation var agent (Anderson 2005). Folkmordet på hererofolket utfördes av tyska soldater på order av den tyske kejsaren. Även här är således nationen den ytterst ansvariga agenten (Sarkin-Hughes 2011).

Dessa händelser ingår i ett större sammanhang som utgörs av den europeiska kolonialismen. Bakom denna historiska epok finns en rad olika agenter. De historiska förloppen ser givetvis olika ut på olika kontinenter, men det går möjligen att skissa en generell bild enligt följande. Först kom upptäcktsresande: Kristoffer Kolumbus, Amerigo Vespucci, Vasco da Gama, Marco Polo, David Livingstone och andra. De har gemensamt att de i en tid av europeisk expansionism och nyfikenhet på världen utanför Europa var framgångsrika upptäckare av andra kontinenter. I deras fotspår kom konkvistadorerna som var beväpnade män som erövrade och säkrade strategiska områden på de nya kontinenterna. Sedan följde företag med uppgiften att exploatera råvaror och mänsklig arbetskraft genom bland annat gruvdrift och plantagejordbruk samt handelsföretag som erhöll koncessioner för handeln inom vissa områden, såsom det holländska ostindiska kompaniet och det brittiska ostafrikanska kompaniet. Gruvor öppnades, plantager anlades och arbetskraft rekryterades. De europeiska kyrkorna upptäckte att kolonierna befolkades av hedningar och man sände ut missionärer till de nya områdena. Sammanfattningsvis var kolonialismen ett resultat av en kombination av politiska, militära, ekonomiska och religiösa agenters handlande, som ytterst legitimerades av de europeiska kolonialmakterna.

\section{Vad gjorde man?}

Den europeiska kolonialtiden var en unik period av erövring och undertryckande av folk på andra kontinenter. De brittiska interneringslägren i Kenya och den tyska krigföringen i Sydvästafrika utgör två exempel på kolonial dominans. I detta avsnitt görs några kommentarer i anslutning till att identifiera «A» $\mathrm{i}$ min modell, d.v.s. handlingar som kan motivera krav på gottgörelse.

Den europeiska kolonialismen varade i cirka 500 år. Det finns ingen möjlighet att i en artikel sammanfatta eller värdera kolonialtidens positiva och negativa följder. Kolonialismens försvarare pekar på att med kolonialismen spreds idéer om demokrati, rättsstaten och mänskliga rättigheter som kom att få en betydelse för kolonierna sedan de blivit självständiga. Å andra sidan innebar kolonialismen underkastelse och exploatering av andra 
folk, liksom kränkningar av just demokratiska principer och mänskliga rättigheter. I vissa fall, som t.ex. det brittiska styret av Uganda och Malaysia, var det koloniala maktutövandet milt och utgick från de koloniserades acceptans, medan i andra fall utsatte kolonialmakten kolonierna för övergrepp och förtryck (Ferguson 2004; Andersson 2005; SarkinHughes 2011). Till kolonialismens bokslut måste också räknas de miljoner människor som föll offer i befrielsekrigen. Bara under befrielsekriget i Algeriet, som i år firar 50 år som självständig nation, krävdes över en halv miljon dödsoffer (White 2012).

I diskussionen om hur kolonialismen ska värderas jämförs ofta kolonialtiden mot en hypotetisk historia utan relationer mellan kolonialmakter och kolonier. Som Daniel Butt påpekar är dock det relevanta kontrafaktiska antagandet inte en hypotetisk historia av isolering utan en med relationer som bygger på ömsesidig respekt mellan nationer och folk (Butt 2009).

Inte alla typer av historiska övergrepp kan vara föremål för gottgörande rättvisa. Michael Schefczyk skiljer mellan «historical ill» (historisk skada) och «historical injustice» (historisk orättvisa). Historiska orättvisor är sådana övergrepp och skador där det går att identifiera de grupper eller personer som bär ett moraliskt ansvar. När det gäller exempelvis angreppskrig och folkmord kan de individer som gav order och de som utförde angreppen i allmänhet identifieras. Exempel på historiska skador är kvinnans underordning och utnyttjandet av klimatresurser genom industrialiseringen. Även om man kan beklaga dessa företeelser, och även om man anser att offren bör kompenseras, går det till skillnad från krig och folkmord inte att identifiera några individer som ansvariga. I linje med distinktionen mellan «historical ill» och «historical injustice» föreslår Schefczyk följande definition av historisk orättvisa: «A historical injustice is a (complex of) natural crime(s), which is (i) legalized and (ii) being perpetrated by morally competent agents» (Schefczyk 2009: 5).

Att ett övergrepp är legaliserat betyder enligt Schefczyk att det när det utfördes inte uppfattades som en lagöverträdelse och att förövaren därmed inte heller riskerade att bli åtalad för övergreppet. Med «natural crime» avser Schefczyk kränkningar av individers rättigheter till liv, frihet och egendom. En «morally competent agent» är någon som har förmågan att skilja rätt från orätt och som därför är moraliskt ansvarig för sin handling (Schefczyk 2009: 6).

Med hjälp av Schefczyks distinktion kan vi se att inte alla historiska övergrepp tillhör kategorin av handlingar som ställer krav på gottgörande rättvisa. Endast de handlingar som utfördes av ansvariga agenter hör dit.

Schefczyk skriver att historiska orättvisor har en «collective nature». De är kollektiva genom att de tolereras av ett lands rättssystem. Det innebär att den politiska gemenskapens kollektiva vilja uttryckt i rådande rättssystem underlåter att åtala för det övergrepp som begåtts.

Schezczyks uppfattning kan tillämpas på diskussionen om gottgörande rättvisa efter kolonialismen. Även om övergreppen i vissa fall utfördes av enskilda individer som inte handlade på direkt uppdrag av kolonialmakten, så är kolonialmakten medansvarig därför att övergreppen tolererades av dess rättsordning. När lång tid förflutit sedan övergreppet 
och det kanske är omöjligt att spåra en enskild gärningsman kan ändå den forna kolonialmakten ställas till svars.

\section{Vilka är offren $(Y)$ ?}

Vilka var - och kanske fortfarande är - kolonialismens offer? Och vem kan därmed kräva gottgörelse? Fyra representanter för offren för den brittiska politiken i Kenya har framträtt inför brittisk domstol. Det är fyra av tusentals medlemmar av kikuyufolket som utsattes för repressionen som var ett svar på Mau-Mau-rörelsens attacker. Offren för Tysklands folkmord i Sydvästafrika är döda. Men deras efterlevande kräver kompensation. Till kolonialismens offer hör tvångsrekryterade plantage- och gruvarbetare, de som spärrades in i interneringsläger och de som behandlades som andra klassens människor och som förnedrades av sina kolonialherrar. Har även deras efterkommande rätt till gottgörelse? Den frågan återkommer jag till senare.

Vilka var då de långsiktiga följderna av kolonialismen? Finns det ett samband mellan kolonialismen och dagens underutveckling i många afrikanska länder? Dessa frågor är mycket svåra att besvara och det råder en oenighet bland forskare om hur sambandet mellan kolonialism och underutveckling skall förstås (Waites 1999; Banerjee, A.V., Benabou, R. Mookherjee, D. 2006; Frank 1967). Om det är så att kolonialismen är en faktor bakom dagens underutveckling i forna kolonier får detta givetvis följder för frågan om vilka som är kolonialismens offer. Till offren hör i så fall inte bara de som under kolonialtiden exploaterades av kolonialmakternas företag, utan även senare generationer som lever i de forna kolonierna hör till kolonialismens offer, om än indirekt. Deras lägre levnadsstandard och deras underordning under en av västländer dominerad världsordning gör dem i så fall också till kolonialismens offer. En sådan uppfattning vilar dock som sagt på en rad kontroversiella premisser.

Kanske man till kolonialismens indirekta offer också kan räkna de människor som dödats och förtryckts som en följd av den «söndra och härska»-politik som fördes $i$ många kolonier. Belgarnas indelning av befolkningen i Ruanda i hutu och tutsie och de folkmord som sedan följde är det mest flagranta exemplet.

\section{Vem bör gottgöra $\left[X^{\prime}\right]$ och vem bör gottgöras [ $\left.Y^{\prime}\right]$ ?}

Gottgörande rättvisa innebär att offren för historiska övergrepp skall kunna kräva kompensation och en ursäkt för tidigare övergrepp. Vilka - om några - kan idag kräva gottgörelse för övergrepp som skedde under kolonialtiden? Kan historiska orättvisor ärvas?

Enligt de regler för en rättvis kompensation som Renée Hill ställer upp bör man skilja mellan kompensation för övergrepp som påverkar en människas välbefinnande och kompensation för äganderättskränkningar. «Compensation must be tied to a clear injury», skriver Hill, och därför kan kompensation för ett övergrepp som påverkat en människas 
välbefinnande bara gå till offret själv och aldrig ärvas av efterkommande. «The injury is like a hole which the compensation strives to fill», skriver Hill vidare (Hill 2004: 403).

Mot Hill kan man invända att även barn till de individer som utsattes för övergrepp skulle kunna kräva kompensation. Även om de inte själva tillfogades skada kan deras liv ha påverkats negativt av den skada som deras föräldrar utsattes för. I den amerikanska diskussionen om gottgörelse till den svarta befolkningen efter slaveriet har förespråkarna exempelvis hävdat att även slavarnas ättlingar har påverkats negativt genom olika typer av försakelser, sämre tillgång till utbildning etc. (Brophy 2006). Samma uppfattning har som vi sett framförts av representanter för hererofolket. Men leder det inte till orimliga konsekvenser att på detta sätt identifiera individer som förtjänar gottgörelse för historiska orättvisor? I varje samhälle har mängder av människor av olika skäl behandlats orättvist, och om detta skall medföra rätt till gottgörelse följer att «... the descendants of the victims of past injustice might include everyone» (Kukathas 2006: 335). Gottgörelse för övergrepp bör således rimligen bara gå till de individer som själva utsattes för övergreppet, inte till deras efterkommande.

De individer som utsattes för övergrepp är en primär grupp som kan ställa krav på gottgörelse. Kan också forna kolonier ställa krav på gottgörelse? Frågan om gottgörande rättvisa efter kolonialismen innefattar nationer på båda sidor. Forna kolonialmakter var nationer som fortfarande existerar: Portugal, Spanien, Storbritannien, Frankrike, Belgien, Nederländerna m.fl. Kolonierna var befolkade av stammar och folkgrupper. Avkoloniseringen innebar att nya nationer skapades som bestod av olika folkgrupper och liten hänsyn hade tagits till etniska och kulturella skillnader när de nya gränserna drogs upp (Chamberlain 2010).

När ärver en nation en skuld och när är en nation ansvarig för tidigare handlingar så att den exempelvis är skyldig att gottgöra en annan nation? ${ }^{1}$ David Miller diskuterar fyra olika situationer där det kan vara rimligt att en part som åsamkats skada får gottgörelse.

I det första fallet har en nation på ett orätt sätt lagt beslag på egendomar, mark eller andra resurser. Då kan den forna kolonin med rätta kräva tillbaka det som tagits. Miller tillämpar följande princip på detta fall: «In the face of competing claims, you cannot bequeath goods to which you do not have a valid title» (Miller 2007: 152).

I det andra fallet handlar den historiska orättvisan inte om stöld utan om exploatering som lett till att kolonisatören har gynnats och den koloniserade missgynnats. Även i detta fall är gottgörelse berättigat, menar Miller. Det faktum att vissa kolonialmakter berikade sig på koloniernas bekostnad innebär att de har en skyldighet att kompensera dessa idag. I sin argumentering vänder Miller på principen om rätten till egendom och arv. Äganderätt och arvsrätt vilar på vissa förutsättningar. Om förutsättningar för dessa rättigheter saknas genom att egendomen är ett resultat av exploatering finns det skäl att kompensera de exploaterades efterlevande.

Det tredje fallet som Miller tar upp är när en kolonialmakt som exploaterade en koloni inte längre gynnas av den tidigare exploateringen, medan den forna kolonin fortfarande lider skada. Kan den forna kolonin kräva gottgörelse i denna situation? I sitt svar utgår Miller från att nationer är «intergenerational communities» (Miller 2007: 154). På samma sätt som nationer kan göra anspråk på att tidigare framgångar utgör en del av deras nati- 
onella arv bör de också ta ansvar för övergrepp och förtryck som de gjort sig skyldiga till. Arvtagaren till en imperialistisk nation som utnyttjade sina kolonier bör således ta ansvar för tidigare övergrepp och kompensera för de skador som kolonin utsatts för.

Slutligen, i det fjärde fallet gynnas inte längre kolonialmakten av den tidigare exploateringen och den har heller inte förorsakat den forna kolonin några bestående skador. Enligt Miller har arvtagaren till den tidigare kolonialmakten även i detta fall en skyldighet att gottgöra den forna kolonin. Gottgörelsen kan emellertid begränsas till en ursäkt (Miller 2007).

Om vi sammanfattar Millers ståndpunkt finner vi att han i samtliga fyra fall argumenterar för gottgörelse, medan gottgörelsen implicerar materiell kompensation i de fall där den forna kolonin fortfarande lider skada.

Miller baserar sina ställningstaganden på två principer. Den första principen utgår från att man inte har rätt till tillgångar som är orätt förvärvade. Enligt den andra principen sträcker sig kravet på rätt förvärv tillbaka i tiden. Hur grundar då Miller denna historiska princip? Vad betyder «intergenerational communities»? Miller hävdar att det finns en kontinuitet mellan olika generationer. I ett sådant historiskt perspektiv erkänner en nuvarande generation både sin skuld till och sitt ansvar för tidigare generationer och försöker också att förbättra framtida generationers livsbetingelser (Miller 2007). Daniel Butt ifrågasätter denna konventionella syn på förhållandet mellan generationer. Han talar istället om «overlapping generations». Generationer följer inte på varandra, de överlappar. För varje år föds ett antal barn och ett antal individer dör. Det innebär att generationer ständigt förnyas. De är "conglomerate collectivities», skriver Butt med anknytning till Peter Frenchs term. En generations identitet är således inte summan av ett bestämt antal individers identiteter, vilket innebär att det är en obruten kontinuitet mellan generationer. Butts ståndpunkt snarare förstärker Millers uppfattning att nationer kan ses som intergenerationella gemenskaper och att det finns en kontinuitet mellan generationer (Butt 2009).

Min slutsats är att individer som utsatts för övergrepp har rätt till gottgörelse av förövaren, däremot övergår inte rätten till de efterkommande. Nationer som utsatts för förtryck eller exploatering, t.ex. genom att de varit koloniserade, har rätt till gottgörelse som innefattar kompensation för bestående skador. Denna rätt tas över av senare generationer så länge skadan består.

\section{Vad är rimlig gottgörelse?}

Låt oss anta att det finns starka skäl för gottgörande rättvisa efter kolonialismen. Vad innebär då gottgörelse och vilka krav kan forna kolonier ställa?

Vi har sett att Aristoteles argumenterade för att gottgörande rättvisa innebär att förhållandet mellan förövare och offer utjämnas. Förövaren har en skyldighet att återgälda de skador som offren åsamkats. Det kan vara möjligt när det gäller konstverk och kulturföremål som fördes från kolonierna till Europa, men knappast när det gäller andra övergrepp. Hur skall forna kolonialmakter återgälda sådant som folkmord, tvångsarbete och koloni- 
alkrig? Varje form av kompensation är otillräcklig. Betyder det att gottgörande rättvisa är orealistisk? Nej, rättvisa behöver inte betyda att en oförrätt kompenseras till fullo. Vad är då rimligt och realistiskt?

Ekonomer erbjuder ett svar på frågan hur man skall bedöma vad som är en rimlig gottgörelse för tidigare oförrätter. Deras svar diskuteras och kritiseras av Debra Satz. Utgångspunkten för den ekonomiska analysen är att skador kan kompenseras monetärt utifrån en preferensskala. En agent är helt kompenserad för en förlust eller skada om han är «...indifferent between his life as it was before the loss and his life as it is now after the loss but with additional goods» (Satz 2007: 178). Som Satz påpekar rymmer denna uppfattning om kompensation en rad problem. Kan verkligen alla typer av skador kompenseras med pengar? Nej, även om grupper som varit utsatta för förtryck ofta kräver ekonomisk kompensation uppfattas detta av offren ofta som otillräckligt. För att relationerna mellan förövare och offer skall återupprättas krävs därutöver också ursäkter och symboliska uttryck för ånger (Satz 2007).

För det andra förutsätter kompensationen en subjektiv preferensskala. Men är en historisk oförrätt alltid kompenserad om ättlingarna till offren anser det? Kanske deras uppfattning är felaktig? Kanske deras subjektiva preferenser inte motsvarar de skador som inträffade? Kanske de har över- eller undervärderat vad som hände tidigare?

För att kunna besvara frågan om vad som kan anses vara en rimlig gottgörelse krävs kunskap om omständigheter och kontext. David Humes diktum «böra förutsätter kunna» kan tillämpas på denna fråga. En bedömning av vad som kan vara en rimlig gottgörelse efter kolonialismen och därmed ett moraliskt krav på den forna kolonialmakten, måste också grundas på en analys av vad som är möjligt vid den tidpunkt när kompensation skall ges. En sådan analys bör ta hänsyn till följande faktorer: 1) den skada som skall gottgöras, 2) tiden som förlöpt sedan övergreppet begicks (utifrån antagandet att gottgörelse är beroende av en tidsfaktor som innebär att ju längre tid som förflutit sedan skadan, desto mindre behov att gottgöra) och 3) förövarens situation idag: hur mycket resurser kan förövaren avstå från utan att hota sin egen överlevnad?

Men innebär inte den tredje faktorn att rättvisan relativiseras? Nej, det är rimligt att hävda att rättvisa uppnåtts när förövarens bidrag innebär en uppoffring som både står i proportion till den skada som offret utsattes för och till vad förövaren förmår. Därmed blir också den uppoffring som krävs olika för en välmående och för en utblottad nation. ${ }^{2}$

Kolonialismen kom att prägla den globala världsordning som vi har idag. Gränserna mellan rika och fattiga länder har sedan koloniernas frigörelse på 1960- och 1970-talen ganska väl följt gränserna mellan kolonialmakter och kolonier. Även om de ekonomiska och sociala följderna av kolonialismen är svåra att fastslå är gottgörelse efter kolonialismen ett viktigt argument för global rättvisa. Kolonialmakterna exploaterade koloniernas naturresurser. De hade kunnat föra en politik som bidragit till koloniernas ekonomiska utveckling. Att det inte gjordes är ett skäl för gottgörande global rättvisa (Butt 2009). Argumenten för distributiv global rättvisa är visserligen övertygande och tillräckliga (Brock 2009; Tan 2004), men till dessa kan också läggas argumentet att de forna kolonialmakterna har en skyldighet att på olika sätt, t.ex. genom skuldavskrivningar och gynn- 
samma handelsavtal, bidra till de forna koloniernas utveckling på grund av den tidigare exploateringen av koloniernas resurser.

\section{Tidsbegränsad gottgörelse?}

Många afrikanska nationer firade 2010 sin femtioåriga självständighet. De sista kolonierna som fick sin frihet var de portugisiska kolonierna Moçambique, Angola och Guinea Bissau som blev självständiga vid mitten av 1970-talet ${ }^{3}$. Kan man uppställa en bortre tidsgräns för när krav på gottgörelse inte länge är berättigade?

Renée Hill hävdar att kraven på gottgörelse har en bortre tidsgräns. Det är knappast rimligt att kräva gottgörelse för övergrepp som hände för mer än femtio år sedan, hävdar hon. Efter en sådan lång tid har offren anpassat sina liv efter den nya situationen och övergreppen fallit i glömska (Hill 2002). Hills tidsgräns kan möjligen gälla för vissa individer som utsatts för övergrepp men knappast generellt. Det visar bland annat offren för Storbritanniens övergrepp mot kikuyo som ju begicks för över femtio år sedan. Även en folkgrupps minne är längre än femtio år, vilket fallet med hererofolkets krav på gottgörelse från Tyskland illustrerar. Effekterna av övergrepp kan också bli bestående; «The lasting effects of population decimation, land dispossession and political marginalisation continue to haunt the Herero identity and impede their economic, social and political progress in modern-day Namibia», skriver Sarkin-Hughes (Sarkin-Hughes 2011: xiii).

Avtar skyldigheter att gottgöra med tiden och upphör skyldigheterna när den generation som utsattes för övergrepp inte längre finns kvar? Utifrån filosofen Daniel Butts teori om nationer som kontinuerliga enheter kan båda dessa frågor besvaras med nej. Som vi sett menar Butt att det är rimligare att uppfatta olika generationer som överlappande än på varandra efterföljande. Detta perspektiv betonar det fortlöpande ansvaret för tidigare övergrepp. Dessutom innebär underlåtelser att kompensera eller be om förlåtelse för tidigare övergrepp en ytterligare orättvisa. Till det första övergreppet läggs därmed en ytterligare kränkning: att inte gottgöra när man har en skyldighet att göra det (Butt 2009).

Det är rimligt att hävda att effekterna av ett övergrepp tenderar att avta med tiden. Minnesbilderna flagnar och den som utsatts för övergrepp anpassar sig successivt till den nya situationen. Det innebär dock inte att kraven på gottgörande rättvisa avtar i samma mån. Det är istället så att underlåtenhet att gottgöra innebär en ny kränkning av offret, vilket ger upphov till än starkare skäl för gottgörelse.

\section{Den gottgörande rättvisans berättigande}

Varför bör forna kolonialmakter gottgöra sina kolonier? För det första är gottgörande rättvisa ett sätt att förverkliga rättvisa. John Rawls hävdar att «Justice is the first virtue of social institutions, as truth is of systems of thought» (Rawls 1971:3). En stat som kränker enskilda medborgare bör gottgöra dessa. Detsamma gäller för nationer. En nation som inte har gottgjort tidigare övergrepp mot andra nationer bär på en skuld gentemot dessa. 
Gottgörande rättvisa är ett sätt att återupprätta ett moraliskt ekvilibrium. Ett moraliskt ekvilibrium föreligger när relationen mellan individer, folkgrupper och nationer kännetecknas av förtroende och ömsesidig respekt. Gränskränkningar, ockupationer, förtryck och exploatering innebär att det moraliska ekvilibriet rubbas och gottgörelse för dessa övergrepp är ett sätt att återställa det.

Jaana Thompson argumenterar för gottgörande rättvisa utifrån skyldigheter som följer av bindande överenskommelser. När en nation ingår ett avtal förutsätts det att avtalet kommer att respekteras och om avtalet bryts av den ena avtalspartnern kan den andra kräva kompensation. Avtal tas över av efterkommande generationer och skyldigheter som följer av avtal är därmed «transgenerational». Skyldigheten att hålla avtal kan således universaliseras. Därav följer att avtalsbrott kräver gottgörelse: «Transgenerational commitments create transgenerational obligations», skriver Thompson (Thompson 2000: 27). Thompsons argument kan utvidgas också till sociala relationer som inte har reglerats i avtal. Nationer och folk har vissa skyldigheter mot varandra. Till dessa hör ömsesidig respekt och fred. Dessa skyldigheter uttrycks bland annat i Läran om det rättfärdiga kriget som tar sin utgångspunkt i naturrättsläran men naturrätten är inte en nödvändig grund för dessa skyldigheter, utan de kan också grundas genom hypotetiska kontrakt (Rawls 1999). Gottgörelse kan avkrävas en nation som kränker de moraliska skyldigheter som nationer har gentemot varandra. Ett ytterligare argument för gottgörande rättvisa efter kolonialismen är således att de forna kolonialmakterna genom sin dominans och exploatering av kolonierna agerade på ett sätt som står i strid med de skyldigheter som ingår i en moraliskt grundad Folkens lag (Law of Peoples). De har därmed skyldighet att gottgöra sina forna kolonier.

Argumenten för gottgörelse är inte bara tillbakablickande utan också framåtsyftande. Forna kolonier liksom folkgrupper som utsattes för övergrepp under kolonialtiden och som fortfarande känner av de historiska orättvisorna kan förväntas hysa agg mot de forna kolonialherrarna. Gottgörelse syftar till att återupprätta relationer och kan förväntas bidra till harmoni och samarbete. Som Jaana Thompson påpekar har nationer ett intresse av fredlig samexistens, men denna är beroende av att det inte finns några bestående motsättningar som är grundade i historiska övergrepp (Thompson 2002). Gottgörande rättvisa kan således bidra till harmoniska relationer mellan forna kolonialherrar och kolonier vilket kan befrämja båda parters utveckling (Walker 2006).

Våra identiteter, både som individer och nationer, formas av tidigare händelser och relationer. Vi ärver skulder och ansvar från våra förfäder och vi bör ta dessa skulder och detta ansvar på allvar (MacIntyre 1981). Vi blir också skamsna om vår nation utövar förtryck och har obetalda historiska skulder; «To be worthy of respect, a nation has to be prepared to fulfil its historical responsibilities», skriver Jaana Thompson (Thompson 2002: 68). För en nation som karakteriseras av rättvisa är det naturligt att gottgöra historiska skulder.

Vilka argument talar då emot gottgörande rättvisa? Det kan hävdas att krav på gottgörande rättvisa innebär att sår som har läkts slits upp och man blir påmind om gamla oförrätter som är glömda. Därmed skulle kraven snarast försvåra goda relationer mellan forna kolonialmakter och kolonier. Å andra sidan är det i de fall där såren inte är läkta, 
och där åtminstone den förorättade parten inte har glömt den historiska orättvisan, som krav på gottgörande rättvisa får gehör.

Ett annat argument mot gottgörande rättvisa är att krav på gottgörelse och kompensation kan skapa konflikter och politisk oro. Kraven kan försämra relationer mellan folk och nationer. Å andra sidan vilar i så fall den rådande samexistensen på en i längden ohållbar grund. Det råder inte «stability for the right reasons» för att låna en term av John Rawls (Rawls 1999: 13). För att en långsiktig fred skall uppnås bör gamla konflikter lösas och gottgöras.

Min diskussion har haft fokus på gottgörelse för koloniala övergrepp och då främst i Afrika. Ett praktiskt problem med att ge afrikanska länder ekonomisk kompensation för övergrepp under kolonialtiden är att pengar riskerar att hamna i fel fickor. Många av dagens afrikanska stater är korrumperade och den ekonomiska kompensationen riskerar därför att förfela sitt syfte. Problemets lösning är att identifiera en mottagare som inte är korrumperad men som kan bidra till utveckling. Kompensation kan också utgå i olika former: direkt ekonomiskt stöd till individer som drabbats, stöd till program för utbildning och hälsovård, förbättrade handelsvillkor, avskrivning av skulder etc. (se de Greiff 2004).

\section{Är de aktuella kraven på gottgörelse berättigade?}

De överlevande Mau-Mau-kämparna som krävt kompensation från Storbritannien har gått till domstol. Den juridiska processen tas inte upp här. De har dock också krävt en ursäkt från Storbritannien, d.v.s. ett krav på gottgörande rättvisa i moralisk mening. Representanterna för hererofolket har hämtat hem sina förfäders skallar från Berlin. Men de har också krävt att Tyskland skall gottgöra dem för vad som hände för över ett hundra år sedan. Vilka krav kan rimligen ställas på Storbritannien respektive Tyskland i dessa fall?

Storbritannien spärrade in misstänkta Mau-Mau-kämpar i interneringsläger. Här utsattes många för misshandel och kränkande behandling. Dessa övergrepp utfördes av ansvariga agenter och de innebar att mänskliga rättigheter kränktes. Övergreppen är därmed exempel på en historisk orättvisa i Schefzyks mening och de som utförde dessa övergrepp handlade på statens uppdrag, ansvaret faller således på Storbritannien.

En möjlig motargumentation kunde vara att lägren och övergreppen var berättigade för att kväsa Mau-Mau-rörelsen som använde terror som vapen för att bekämpa britterna och kenyaner som var lojala med britterna (Anderson 2005). Därmed skulle det heller inte finnas skäl för gottgörelse till dem som internerades i lägren. Denna uppfattning förutsätter dock bland annat att den brittiska kontrollen av Kenya var moraliskt legitim och att lägren och övergreppen var berättigade medel att upprätthålla denna kontroll. Båda antagandena är ohållbara eftersom de står i strid med principer om nationers rätt till självbestämmande och mänskliga rättigheter.

Därmed bör Storbritannien, som länge försökt att dölja vad som hände i interneringslägren, utifrån principer för gottgörande rättvisa erkänna övergreppen, gottgöra offren 
och intyga att man inte ämnar utföra denna typ av handlingar i framtiden. Att övergreppen skedde för femtio år sedan saknar betydelse. Det är uppenbart att offren fortfarande plågas av vad som hände då. Storbritannien har nyligen betalat ungefär tre miljoner pund till offren for brittiska soldaters tortyr i Irak (Sapsted 2011). Denna kompensation kan uppfattas som prejudicerande och borde få konsekvenser för Mau-Mau-kämparnas krav.

Hererofolkets representanter har nyligen hämtat hem de skallar som togs till Tyskland i början av 1900-talet. Tyskland hade inte rätt att förfoga över dessa och återförandet till Namibia kan motiveras av Millers första princip för gottgörande rättvisa. Man har dock också krävt gottgörelse för Tysklands folkmord. Folkmordet leddes av general van Trotta på order av Kejsar Wilhelm II. Det är därmed otvivelaktigt den tyska nationen som bär ansvaret. Finns det då något möjligt försvar för tyskarnas folkmord som skulle kunna försvaga kraven på gottgörelse? Det är svårt att hitta något sådant. Den tyska dominansen av Sydvästafrika var inte moraliskt försvarbar, anledningen till övergreppen var konstruerade misstankar om förestående uppror osv. (Gewald 1999; Sarkin-Hughes 2011). Även i detta fall skulle ett försvar för tyskarnas övergrepp förutsätta att principer om nationers rätt till självbestämmande och mänskliga rättigheter ifrågasattes.

Att det var ett krig som fördes under den tyska kejsartiden saknar betydelse för frågan om gottgörelse. Den tyska nationen existerar idag, men med ett annat styrelseskick. Har det då någon betydelse att folkmordet ägde rum för så länge sedan? Har inte skadorna läkts på över ett hundra år? Många ättlingar till de personer som mördades och utsattes för övergrepp vittnar om att såren inte har läkts. Folkmordet drabbade hererofolket på flera sätt. Deras antal decimerades, de drevs bort från sina traditionella områden och deras etniska integritet och kultur skadades. Då dessa skador består finns det skäl för att Tyskland gottgöra hererofolket. Att man nonchalerat de krav på gottgörelse som representanter för hererofolket tidigare fört fram spär också på skulden; skulden gäller inte bara det folkmord som utfördes för över ett hundra år sedan utan också för vägran att gottgöra de övergrepp som då skedde.

Både kraven från de forna Mau-Mau-kämparna och hererofolket visar att kolonialismen fortfarande kastar en skugga över vår samtid. Arvet efter kolonialismen har betydelse för den aktuella diskussionen om global rättvisa.

\section{Noter}

1 En terminologisk kommentar: Finns det skäl att tilldela ansvar till en nation eller till en stat? Argument för att i detta sammanhang använda termen stat är att en stat är en formellt konstituerad enhet med suveränitet över ett territorium. Därmed kan en stat handla gentemot andra stater på basis av beslut fattade i legitima organ och det är möjligt att utkräva ansvar för handlandet. Det är också den enhet som har internationell status. Internationella avtal ingås mellan stater och staters relationer är reglerade enligt folkrätten.

Det som talar för att termen nation är att föredra är att nationen representerar en historisk kontinuitet. Som John Stuart Mill påpekar är nationalkänslans starkaste grund «... identity of political antecedents; the possession of national history, and consequent community of recollections; collec- 
tive pride and humiliation, pleasure and regret, connected with the same incidents in the past» (Mill 1993).

Det som talar för att man bör tala om stat i detta sammanhang är således att en stat är en agent, medan det som talar för att nation är att föredra är att nationsbegreppet har en historisk relevans vilket är av betydelse när frågan gäller historisk rättvisa. Nationen har en tydligare kontinuitet bakåt i historien än staten. Det är exempelvis rimligt att se att den svenska nationen går tillbaka till 1500talet, medan den svenska staten inte lika uppenbart äger samma historiska kontinuitet.

Ett ytterligare skäl som David Miller för fram är att den koloniala praktiken innefattade en rad olika agenter: företag, individer och givetvis också staten själv genom sina kolonialadministratörer och soldater. För att kunna inkludera dessa olika agenter är nationen, som ett vidare begrepp, att föredra (Miller 2007). Det finns skäl för båda termerna men jag väljer att använda termen nation i detta sammanhang där det är historien som fokuseras.

2 Denna uppfattning kan illustreras av ett exempel från Moçambique. Om den forna kolonialmakten Portugal skulle gottgöra Moçambique för de skador som de tillfogade Moçambique under kolonialtiden, inklusive det krig man på 1960- och 1970-talen förde mot befrielserörelsen Frelimo skulle det förutsätta väldiga insatser från Portugals sida. Det är dock knappast rimligt att idag kräva detta av Portugal som befinner sig i en ekonomisk kris. Uppoffringen skulle i dagens läge vara alltför stor. Men, det kan vara rimligt att kräva att Portugal överlämnade Cabora Bassa-dammen som byggdes under kolonialtiden till Moçambique utan krav på ersättning, vilket man dock inte gjort (Valy 2011).

3 Med några undantag, såsom Hong Kong.

\section{Litteratur}

Anderson, D. (2005) Histories of the Hanged. The Dirty War in Kenya and the end of Empire. New York and London: Norton and Company.

Aristoteles (1988) Den Nikomakiska Etiken. Göteborg: Daidalos.

Banerjee, A.V., Benabou, R. \& Mookherjee, D. (2006) Understanding Poverty. Cary: Oxford University Press.

Barkan, E. (2000) The Guilt of Nations. New York: W.W. Norton, New York.

Brophy, A. (2006) Reparations: Pro and Con. Cary: Oxford University Press.

Brocks, G. (2009) Global Justice, A Cosmopolitan Account. Oxford: Oxford University Press.

Butt, D. (2009) Rectifying International Injustice. Principles of Compensation and Restitution Between Nations. Oxford: Oxford University Press.

Casciani, D. (2011) Mau Mau case: UK government cannot be held liable. Hämtad 7. mars 2011 från http://www.bbc.co.uk/news/uk-12994190

Chamberlain, M.E. (2010) The Scramble for Africa. Harlow: Pearson.

De Greiff, P. (2007) Justice and Reparations. I Reparations: Interdisciplinary Inquiries, red. J. Miller \& R. Kumar, s. 153-176. Oxford: Oxford University Press.

Ferguson, N. (2004) Empire: The Rise and Demise of the British World Order and the Lessons for Global Power. New York, NY, USA: Basic Books.

Frank, A.G. (1967) Capitalism and Underdevelopment in Latin America. New York and London: Monthly Review Press.

Gewald, J.-B. (1999) Hereros Heroes. Oxford: James Currey and Ohio University Press.

Hill, R. (2002) Compensatory Justice: Over Time and Between Groups. The Journal of Political Philosophy, 10 (4), s. 392-415.

Howard-Hassmann, R. (2008) Reparations to Africa. Philadelphia: Penn.

Kukathas, C. (2006) Who? Whom? Reparations and the problem of agency. Journal of Social Philosophy, 37 (3), s. 330-341. 
Kymlicka, W. (2002) Contemporary Political Philosophy: An Introduction. Oxford: Oxford University Press.

Lean, S. (2003) Is Truth Enough? Reparations and Reconciliation in Latin America. I Politics and the Past - On repairing historical injustices, red. J. Torpey, s. 169-192. Lanham: Rowman and Littlefield.

Locke, J. (1977) Two Treatises of Government. London: Dent.

Lyons, D. (1982) The New Indian Claims and Original Rights to Land. I Reading Nozick. Essays on Anarchy, State and Utopia, red. J. Paul, s. 355-379. Oxford: Blackwell.

MacIntyre, A. (1981) After Virtue. London: Duckworth.

Mill, J.S. (1993) Utilitarianism: On liberty; Considerations on representative government; Remarks on Bentham's philosophy. London: Dent.

Miller, D. (2007) National Responsibility and Global Justice. Oxford: Oxford University Press.

Nozick, R. (1974) Anarchy, State and Utopia. Oxford: Basil Blackwell.

Rawls, J. (1971) A Theory of Justice. Cambridge: Harvard University Press.

Rawls, J. (1999) The Law of Peoples. Cambridge: Harvard University Press.

Sapsted, D. (2011) Report: British army cleared of 'systematic' Iraq torture. Hämtad 5. december 2011 från http://www.thenational.ae/news/worldwide/europe/report-british-army-clearedof-systematic-iraq-torture

Sarkin-Hughes, J. (2011) Germany's genocide of the Herero: Kaiser Wilhelm II, his general, his settlers, his soldiers. Cape Town: UCT Press.

Satz, D. (2007) Countering the Wrongs of the Past: The Role of Compensation. I Reparations: Interdisciplinary Inquiries, red. J. Miller \& Kumar, R., s.153-176. Oxford: Oxford University Press.

Schefczyk, M. (2009) Untangling Historical Injustice. International Justice Review 9 (1), s. 4-9.

Stanford Encyclopedia of Philosophy. Hämtad 8. februari 2012 från http://plato.stanford.edu/

Tan, K.-C. (2004) Justice Without Borders. Cambridge: Cambridge University Press.

The Telegraph (2011) Namibia to collect Herero skulls from Germany. Hämtad 25. september 2011 från http://www.telegraph.co.uk/news/worldnews/africaandindianocean/namibia/ 8788072/Namibia-to-collect-Herero-skulls-from-Germany.html

Thompson, J. (2002) Taking Responsibility for the Past, Reparation and Historical Justice. Cambridge: Polity.

Torpey, J. (2003) Politics and the Past. On repairing historical injustices. Lanham: Rowman and Littlefield.

Valy, B. (2011) Mozambique takes over Cahora Bassa Dam, Afrol News. Hämtad 25. september 2011 från http://www.afrol.com/articles/27390

Villa-Vicencio, C. (2009) Walk with us and Listen. Georgetown: Georgetown University Press.

Waitess, B. (1998) Europe and the Third World. From Colonisation to Decolonisation c. 1500-1998. New York: St Martin's Press.

Waldron, J. (1992) Superseding Historic Injustice. Ethics, 103 (1), s.4-28.

Walker, M.U. (2006) Moral Repair. Reconstructing Moral Relations after Wrongdoing. Cambridge: Cambridge University Press.

White, M. (2012) Necrometrics. Hämtad 15. april 2012 från http://necrometrics.com/ 20c300k.htm\#Algeria 